\title{
Teaching Reform of Clothing Drafting Course in Fashion Design Major
}

\author{
Wenqiang Chen, Junlei Chen \\ Xijing University, Xi’an, Shaanxi, 710123
}

Keywords: fashion design major; clothing drafting; teaching reform

\begin{abstract}
Clothing drafting and technology are core courses in fashion design major at present. Fashion design is mainly to cultivate students' actual operational ability and conform to current social development requirements so as to provide excellent inter-disciplinary talents for clothing production. Technical course of fashion design major mainly relies on technical training to cultivate students' operational ability, improve students' cognition of the market, and further help students to adapt to job market and realize their own sustainable development. This paper mainly studies educational reform measures of clothing drafting courses in fashion design major.
\end{abstract}

During course teaching of fashion design major, major courses include clothing drafting, fashion technology, and etc. This is a professional technological course closely related to actual operation of corporate production. Through this course, students' actual operation abilities can be cultivated comprehensively. Teaching quality of teachers can influence students' professional qualities of the course and their working abilities in the future. Therefore, in order to cultivate students into compound type talents, this course needs to be reformed and innovated.

\section{Current Teaching Situation of Fashion Design Major}

\subsection{Non-uniform course orientation}

During current teaching process of fashion education, the teaching methods are based on professional technology with professional art as guidance. After the reform of "Valuing theories and grasping practice", teaching structure of fashion design got valued comprehensively. However, since cognition on fashion design is still vague, different schools have different understandings on this course. Curriculum orientation on sewing technology of clothes is non-uniform. Some are oriented to teaching artistic design theories and practices of sewing to students; some are oriented to clothing drafting plate-making and the essence of fashion design is embodied; some are oriented to combining clothing drafting and process design and valuing the cultivation of students' professional qualities and further valuing practical teaching of fashion design. Through analysis, it is found out that different course orientation can embody the pertinence of clothing drafting and design. Therefore, various curriculum orientations can influence students' learning goals and teaching quality directly.

\subsection{Unstable leaning thoughts}

At present, when some schools are recruiting students of the major of Clothing Drafting, most students do not have art foundation. Because of the influences of traditional educational thoughts, most people do not pay enough attention on clothing drafting, so when most students are registering for examinations, they do not have rich interests on clothing drafting. Therefore, when students are learning clothing drafting, it is very difficult to stimulate their learning enthusiasm; in turn, they would have perfunctory attitude on the learning methods and it would be difficult to complete and enrich themselves in the learning process and apply what they have learned into practice. Since their learning thoughts are unstable, it is very difficult for them to learn real professional knowledge. Since students are usually impatient when learning clothing drafting course, their enthusiasm is usually not high, which results to student's poor actual operation ability; they cannot complete learning plans of graphic design and three-dimensional design accurately or even conduct 
comprehensive design on technological drafting innovation.

\subsection{Dull teaching content, not conforming to production demands}

The current clothing production process pays attention to the style and technological means of clothes, and then it can get standards of corporate production. However, some schools do not pay attention to the teaching of fashion design clothing drafting; they still adopt traditional backward technology design methods so that students cannot learn technology design that the society needs and students cannot apply knowledge points into design in future work. Since the update speed of the teaching materials is slow, technological design means of clothes is backward; in fashion design course, the teaching content lacks pertinence of the post severely so that when students are learning, they cannot learn integrate knowledge about structural art of clothes, and it may influence professional development of students.

\subsection{The lack of actual demands of clothing market combined in teaching}

The current clothing design is to cultivate students' autonomous design ability and actual operation ability so that what students learn can conform to the current market demands. However, the current learning points are not clear enough; the teaching process does not pay attention to the cultivation of students' comprehensive abilities so that students are not familiar with new technological structure; also, during the design and production process, students cannot integrate current social demands into the design and cannot produce models of clothes with flexible means; furthermore, students' clothing design ideology cannot be realized.

\section{Reform Measures of Teaching Content of Fashion Design Technology}

\subsection{To conform to social demands}

To the current social development demands, the society has different demands on the structural design technology of clothes. It should both guarantee the quality of the clothes and represent the contemporary society's ideology of clothes so that clothes design production can have recognition of the public. Such ideology needs to integrate design philosophy and demands that the current society needs into fashion design so that clothes design production is more modern. Therefore, in the teaching of current clothes design production, teachers should integrate new production demands into daily teaching continuously so as to guarantee that students can conform to current production demands when learning clothes design production. Teachers should teach with plans according to demands of current corporate production demands. By integrating such position technology into teaching, students can understand production standards of industry, technology design production and quality of clothes more deeply; also, students can be helped to learn technology that industry needs in future studies and can exert their professional abilities in their future posts.

\subsection{To be close to realities}

With the continuous development and progress of the current society, clothes technology production design has been more and more valued by the current society. For the purpose that students can design clothes that conform to social demands in future social practical process of fashion design, teachers should combine actual demands of social development during teaching and update teaching content timely. By utilizing new project teaching, it can train students during curriculum learning by combining potential demands of the market and fashionable elements of clothes so as to provide comprehensive help to students after graduation and their professional clothes design production can get comprehensive acknowledgement by the society.

\section{To improve teaching methods and enrich teaching forms}

It needs us to combine contemporary clothes development trend in teaching process and change the current traditional teaching mode to help students obtain rich professional knowledge in 
learning stage and further improve their professional technical standards to a corresponding standard. Traditional teaching mode usually adopts closed teaching methods. Therefore, it leads to the result that students' learning content cannot satisfy development demands of the current society. In order to improve the learning quality of current students comprehensively and guarantee students' professional techniques, it needs teachers to bring in more reasonable teaching methods in teaching, enrich current teaching content, improve and enrich teaching methods. They should organize students to enter the market according to actual teaching demands so that students can understand current society's demands on fashion industry; by combining actual practices, students can understand trend of current fashion design. By having students study new technology which is brought in by aiming at clothes market, students can grasp requirements of the market reasonably. In teaching, teachers establish projects through various design means and technologies so that students can grasp design development, brand analysis of clothes during class learning; also, students can grasp distinctly, understand clearly and grasp the key points of fashion design from selection of projects, to study, development, design, production and market injection and so on. Through these project researches, teachers can enrich students' major and further create excellent fashion design works.

\section{To strengthen actual teaching and cultivate post abilities}

During drafting design process of clothes, it mainly relies on strong practice. Through practical design and production, students can grasp some professional technologies in fashion design, such as fashion brand, technological process and so on. During teaching, teachers should cultivate students with pertinence and bring practice of clothes into studies. Teachers should plan practical teaching according to teaching objectives reasonably, train students to operate professional techniques with purposes and train students' career post abilities aiming at students' employment demands. During students' practical teaching, teachers should divide technique training into several aspects of module teaching compressively: firstly, basic technique training to students and the main purpose is to strengthen plate-making of clothes and general technique training; secondly, professional technique training on this basis. Teachers should set up professional training projects in classes according to demands and actual requirements of clients so that students can complete regulated professional technique training in time. This professional training can guarantee clothes that students design and produce can conform to contemporary standards. It mainly tests students' technique abilities and innovation abilities. During teaching, it should pay attention to students' quality ability cultivation continuously and present according to career technique the society needs and further promote students' technique standards. During career post technique training, professional technique should be integrated into training so that students can be familiar with links of clothes design technique; also, they can grasp links such as clothes assembly line, quality of clothes, and test of clothes and so on. Through practical operation of different post demands of the enterprises, it can guarantee that students can obtain professional training and technique training so as to strengthen students' technique abilities of career posts and further promote students' career ability after they enter the job market.

\section{To encourage students' autonomous learning}

During the teaching process of fashion design production, teachers should guide students for technical autonomous learning, which can guarantee students to apply professional skills for creation more reasonably in study and treat this as the learning goal of fashion design production. Teachers encourage students according to real situation, confirm good learning goal, encourage students to look up materials as often as possible during learning process, understand the current trend of fashion design , cultivate students to be good at observe characteristics of different clothes brands, find main technologies and further broaden their professional vision. By encouraging students and cultivating them to design and study fashion design autonomously, students can explore new knowledge actively and improve their learning ability and practical operational 
abilities.

\section{Conclusion}

Fashion is a major with modernity and challenge. With the acceleration of global economic integration, fashion industry has been connecting with the world gradually, which is the general trend of fashion development. Fashion design needs large numbers of hi-tech inter-disciplinary talents. In order to guarantee that students can keep a foothold in future fashion field, teachers should reform and innovate professional curriculum content continuously so that students can not only obtain professional knowledge training but also their actual operational abilities can be represented excellently.

\section{Acknowledgment}

Xijing University Educational Reform Project: Major of Fashion Design Clothing Drafting Course Digital Teaching Reform.

Project Number: JGYB1637

\section{References}

[1] Liu Pengpeng, Bai Yuxi. Study on the Work Stress of Knowledge Workers in Garment Industry [J]. Journal of Beijing Institute of Fashion (Natural Science Edition). 2010 (03)

[2] Ye Hong. Discussion on the fashion designer style of humanized management [J]. Popular colors. 2010 (03)

[3] Sun Enle, Xie Qing. Research on Personnel Management of Guangdong Small and Medium-sized Garment Private Enterprises [J]. Silk. 2007 (11)

[4] Guo Daning, Wang Lei, Chen Cheng. Product Life Cycle Management (PLM) and Its Application in Garment Enterprises [J]. Journal of Donghua University (Natural Science). 2005 (02) 